\title{
The Possible Ameliorative Effect of Melatonin on Oxidative Stress and Delayed Apoptosis in Rat's Brain Exposed to Deltamethrin
}

\author{
Shereen Abd-elhakim El-sherbeney, Hala M. Ahmed', Nashwa F. El-Tahawy², \\ and Ahlam Mohamed Abdalla 3
}

\footnotetext{
${ }^{1}$ Forensic Medicine and Clinical Toxicology department

${ }^{2}$ Histology department

${ }^{3}$ Biochemistry department
}

Faculty of Medicine, Minia University, Minia, Egypt

\begin{abstract}
Deltamethrin is a broad spectrum, non- cumulative, fast acting neurotoxic synthetic pyrethroid. The aim of this study was to analyze the neurotoxicity induced by deltamethrin which caused neuro-oxidative stress, histopathological \& immunohistochemical changes in adult male Wistar rats and to evaluate the possible ameliorative effect of melatonin. Melatonin $(10 \mathrm{mg} / \mathrm{Kg}$, once daily), ethanol $99 \%$ ( $1 \mathrm{ml} / \mathrm{kg}$, once daily), corn oil $(0.005 \mathrm{ml} / \mathrm{Kg}$, once daily), deltamethrin $(12.5 \mathrm{mg} / \mathrm{Kg}$, once daily), and melatonin $(10 \mathrm{mg} / \mathrm{Kg})+$ deltamethrin $(12.5 \mathrm{mg} / \mathrm{Kg})$ combination were given to rats I.P for 8 weeks. By the end of $8^{\text {th }}$ week, rats given deltamethrin alone had significantly higher MDA (malondialdehyde), lower reduced glutathione and catalase levels in the hippocampus and lower ACTH (adrenocortocotrophic hormone) \& cortisol hormone levels than the control group. Co- treatment of deltamethrin with melatonin had an ameliorative effect on the previous parameters. Light microscopic investigations revealed that deltamethrin caused marked degenerative changes in the hippocampus \& pituitary gland of rats. Mild degenerative changes were observed in rats received deltamethrin + melatonin combination. Immunohistochemical studies revealed that deltamethrin caused marked expression of P-53 (a marker for apoptosis) in the hippocampus \& pituitary gland. Mild expression of P-53 was observed in rats received deltamethrin \& melatonin combination. Thus, deltamethrin can induce oxidative damage in rat brain \& melatonin has an ameliorative effect against this damage.
\end{abstract}

Keywords deltamethrin, neurotoxicity, histopathology, immunohistochemistry, melatonin

\section{Introduction}

$\mathrm{P}$ yrethroid compounds are synthetic analogs and derivatives of natural pyrethrins. Synthetic pyrethroids are used as insecticides on a worldwide scale. They are increasingly applied in agricultural and household settings for the prevention and treatment of ectoparasites and for control of mosquitoes and fleas in kitchens and bedrooms (Fatma, 2011).

Pyrethroid compounds are considered safe as compared to organochlorine, organophosphate and carbamate compounds owing to its less persistence in nature (Pratap and Vandana, 2008). The wide use of synthetic pyrethroids is increasing worldwide pollution risks. The synthetic pyrethroids are among the most potent and effective insecticides available, account for more than $30 \%$ in the world market (Moore and
Waring, 2001). The low effect of toxicity of pyrethroid insecticides on mammals and birds and their limited soil persistence has encouraged the widespread and increasing use of pyrethroids in agriculture, as potent agents against pests (Ko"pru"cu" and Aydin, 2004).

Diet is a primary route of exposure to pyrethroids among non-occupationally exposed individuals, but permethrin and other pyrethroid insecticides have also been measured in a high proportion of household dust samples suggesting that the home environment may also comprise a major exposure source (John et al., 2009).

Deltamethrin is a non-composite synthetic pyrethroid; a broad spectrum, non-cumulative insecticide; a fast-acting neurotoxic agent with good contact and stomach action and no fumigant action. Its 
biological activity is very stable in the environment since it has good residual activity on many insects and most surfaces. Deltamethrin is of moderately high toxicity in mammals, and is readily metabolized with rapid loss of toxicity. It has a repellent effect for some insects (Ercüment et al., 2010).

Pyretheroids may cause various side effects, e.g. change in DNA structure (Bagchi et al., 1995), cause of sperm malformations, generation of reactive oxygen species (Bagchi et al., 1996), increase in the level of free radicals, inhibition of specific enzyme (Lee and Steinert, 2003), influence on antioxidant defense system (Ekinci and Beydemir, 2010) and act as inducers of heat shock protein in tissues and cells in different organisms (Ceyhun et al., 2010).

Melatonin (5-Methoxy- $N$-acetyltriptamine) is an indol synthesized from tryptophane in various organs such as the pineal gland, retina, intestine, bone marrow cells and skin. It is very lipophilic and crosses all lipidic membranes, including the cytoplasmic membrane. As a result, melatonin reaches the cytosol of all cells; thereby its function is not restricted solely to a certain group. At the molecular level, its participation in steroidogenesis has been demonstrated (Karbownik and Reiter, 2000; Tan et al., 2003).

In spite of the little researches evaluating the effect of deltamethrin on the hippocampus \& pituitary gland which made the objective of this study was to analyze the neurotoxicity induced by deltamethrin on these parts and to evaluate the possible ameliorative effect of melatonin.

\section{Material and Methods}

\section{Animals}

This work was carried out on 60 adult Wistar male rats (weighing approximately 200- $250 \mathrm{gm}$ ) of twelve weeks of age. The animals were obtained from Minia University Laboratory Animals Growing Center. The rats were housed in plastic cages, fed a standard laboratory diet and water and maintained at a laboratory temperature of $22 \pm 3^{\circ} \mathrm{C}$ and exposed to a 12 light, dark cycle. All aspects of animal care and treatment were carried out according to the local guide lines of the Ethical Committee of Faculty of MedicineMinia University.

\section{Chemicals}

Deltamethrin (98\%) and Melatonin (white crystals) were obtained from Sigma Pharmaceutical Company. Ethanol (99\%) acting as a solvent for melatonin and it was obtained from El- Nasr Pharmaceutical Company.

\section{Animal treatment schedule}

The animals were divided into 6 groups each composed of 10 rats as follow:

- Group (1) (control group): fed a standard laboratory diet and water.

- Group (2) (corn oil- treated group): the rats were given corn oil (a solvent for deltamethrin). It was given at a dose of $0.005 \mathrm{ml} / \mathrm{Kg}$ bw daily by intraperitoneal (I.P) injection for 8 weeks to test the effect of repeated exposure of deltamethrin.
- Group (3) (Ethanol- treated group): the rats were given $1 \mathrm{ml} / \mathrm{kg}$ bw of ethanol $99 \%$ (a solvent for melatonin) daily by I.P injection for 8 weeks. Ethanol must be diluted with saline just before injection with final concentration of ethanol was $2 \%$ according to Crespi et al., 1994.

- Group (4) (Melatonin-treated group): melatonin was given at a dose of $10 \mathrm{mg} / \mathrm{kg}$ bw daily I.P for 8 weeks according to Hala et al., 2009 .Melatonin was dissolved in $99 \%$ ethanol then diluted with saline just before injection with final concentration of ethanol was 2\% (Crespi et al., 1994).

- Group (5) (Deltamethrin- treated group): deltamethrin dissolved in corn oil was given at a dose of $12.5 \mathrm{mg} / \mathrm{kg}$ bw daily I.P for 8 weeks according to Aiguo and Yugu, 2000. This dose is $15 \%$ of $\mathrm{LD}_{50}$ of deltamethrin (Sheets et al., 1994).

- Group (6) (Melatonin + Deltamethrintreated group): the rats were given melatonin + deltamethrin by the same previous doses I.P for 8 weeks. Melatonin was injected $30 \mathrm{~min}$ before the injection of deltamethrin, since it has been shown that the peak concentration of the hormone in the brain is reached $30 \mathrm{~min}$ after the systematic administration of exogenous melatonin (Crespi et al., 1994).

Rats were sacrificed by decapitation after light ether anesthesia and dissected at the end of $8^{\text {th }}$ week of treatment. All approved conditions used for animal housing and handling were considered. The experimental protocol used followed the regulations for administration and painless sacrifice of the experimental animals. The animals were acclimatized prior to starting dosing for a period of one week. The brain was dissected and the hippocampus and the pituitary gland were separated and subjected to light microscopic and immunohistochemical investigation. The remaining hippocampus tissue was subjected to biochemical studies (malondialdehyde (MDA), reduced glutathione (GSH) and catalase levels). Blood samples were collected for assaying the level of serum cortisol hormone and plasma adrenocorticotropic hormone (ACTH).

\section{Biochemical studies}

At the end of 8 weeks, blood samples were withdrawn from the recto-orbital plexus of veins using a capillary pipette and collected in heparinised tubes containing $5000 \quad \mathrm{I} . \mathrm{U} / \mathrm{ml}$ heparin sodium and centrifuged at $3000 \mathrm{rPm}$ for $15 \mathrm{~min}$. Plasma was separated and stored at $-20^{\circ} \mathrm{C}$ until required. The samples were subjected for the estimation of:

1- Serum cortisol: cortisol ELISA kits were obtained from antibodies- online $\mathrm{GmbH}$ Company (Herrero et al., 2006).

2- Plasma ACTH: ACTH ELISA kits were obtained from GenWay Biotech Company (Krieger et al., 1979). 
Malondialdehyde (MDA), reduced glutathione (GSH), and catalase assays

Hippocampus was separated and homogenized in 1:10 (wt: vol) $0.1 \mathrm{M}$ phosphate buffer ( $\mathrm{pH} 7.4$ ) by the use of a Teflon headed homogenizer. Triton x100 and protease inhibitor cocktail were added. The homogenates were centrifuged at $6.000 \mathrm{~g}$ for $10 \mathrm{~min}$ at $4^{\circ} \mathrm{c}$ and the supernatant was used to measure MDA, GSH and catalase levels. MDA kits were obtained from Bio-diagnostic Company, colorimetric method (Ohkawa et al., 1979). While GSH kits were obtained from Bio-diagnostic Company, colorimetric method (Beutler et al., 1963). Catalase kits were obtained from Bio-diagnostic Company, colorimetric method (Aebi, 1984).

\section{Histopathological studies}

Brains were removed intact and were fixed in $10 \%$ buffered formalin followed by paraffin embedding using routine procedures. Seven- micrometer sections were deparaffinized with xylene and stained with haematoxylin and eosin (H\&E) to be viewed by light microscopy to examine the hippocampus and pituitary gland (Bancroft et al., 2002).

Other sections were mounted on poly-LLysine coated slides and used for immunohistochemical staining with anti p-53 according to the previously published protocol (Cote et al., 1993). Briefly, sections were deparaffinized, rehydrated, and in order to retrieve antigen, sections were incubated with $0.1 \%$ trypsin and $0.1 \% \mathrm{CaCl} 2$ $2 \mathrm{H} 2 \mathrm{O}$ in $50 \mathrm{mM}$ Tris buffer at $\mathrm{pH} 7.4$ at $37 \mathrm{oC}$ for 120 minutes. Sections were soaked in absolute methanol containing $0.3 \%$ hydrogen peroxide for $30 \mathrm{~min}$ at room temperature to eliminate the endogenous peroxidase activity. The sections were then incubated with $1.5 \%$ non-immunized goat serum for $30 \mathrm{~min}$ at room temperature, then incubated with diluted p-53 (1:500) for $30 \mathrm{~min}$ and washed three times with phosphate buffer saline (PBS). Thereafter, the sections were incubated with biotinylated goat anti-mouse Ig serum for $60 \mathrm{~min}$. After being washed with PBS, the sections were incubated with avidin/ biotin peroxidase complex. Sites of peroxidase binding were detected using chromogenic 3, 3-diaminobenzidine (DAB) terahydrochloride substrate. Tissue sections were counterstained with haematoxylin (Mabuchi et al., 2001).

Tissue sections (hippocampus and pituitary gland) were examined and images were digitally captured using a hardware consisting of high resolution color digital camera mounted on an Olympus microscope (Olympus BX51, Tokoyo, Japan) and connected to a computer, then dealt with using adobe Photoshop.

\section{Statistical analysis}

Values were expressed as mean \pm standard deviation (SD). The data were analyzed by using SPSS for windows (version 10.0). The significance of differences was calculated by using student $t$ - test and Chi- square test. $\mathrm{P}<0.05$ was considered significant.

\section{Results}

\section{Results of biochemical studies}

The control, corn oil, ethanol and melatonin- treated groups had equivalent MDA level in the hippocampus samples at the end of $8^{\text {th }}$ week, but the deltamethrin and melatonin plus deltamethrin treated groups had significantly higher MDA level when compared with the control group. However, the melatonin plus deltamethrin- treated group had significantly lower MDA level when compared with the deltamethrintreated group (table 1).

The corn oil, ethanol and melatonin- treated groups did not differ significantly from the control rats in terms of GSH level, but the deltamethrin and melatonin plus deltamethrin - treated rats had significantly lower reduced glutathione level when compared with the control rats. However, melatonin plus deltamethrin- treated rats had significantly higher reduced glutathione level when compared with the deltamethrin- treated group (table 2).

The control, corn oil, ethanol and melatonintreated groups had equivalent catalase level, but the deltamethrin and melatonin plus deltamethrin treated groups had significantly lower catalase level when compared with the control group. However, melatonin plus deltamethrin treated group had significantly higher catalase level when compared with the deltamethrin treated- group (table 3 ).

The corn oil, ethanol and melatonin- treated groups did not differ significantly from the control rats in terms of ACTH and cortisol hormone levels, but the deltamethrin and melatonin plus deltamethrin - treated rats had significantly lower ACTH and cortisol hormone levels when compared with the control rats. However, melatonin plus deltamethrin- treated rats had significantly higher ACTH and cortisol hormone levels when compared with the deltamethrin- treated group (table 4).

\section{Histological and immunohistochemical results}

The control, corn oil, ethanol and melatonin- treated groups (group 1-4) showed normal laminar organization of the hippocampus. The hippocampus proper or cornu ammonis (CA) divided into CA1, CA2, CA3 and CA4 zones, and the dentate gyrus (DG) (fig. 1a). The hippocampus formed of 3 layers. These 3 layers are the superficial molecular layer, consisting of nerve fibers and scattered small neurons; the pyramidal layer, consisting of many large pyramid-shaped neurons; and the inner polymorphic layer, containing dendrites of the pyramidal cells. The pyramidal cells were densely packed and characterized by vesicular nuclei with prominent nucleoli. The same arrangement was observed in the DG but the cells were granular instead of the pyramidal. Neuropil is a region between neuronal cell bodies in the gray matter of the brain. It consists of a dense tangle of axon terminals, dendrites and glial cell processes. It was dense and tightly packed (fig. 1b \&c).

The deltamethrin- treated group (group 2) showed disturbed laminar organization of the hippocampus and widely separated cells were observed especially in zones CA1 and CA3 (fig. 2a). There was 
increase in the amount of the degenerated cells with densely stained, shrunken acidophilic cytoplasm and dark condensed pyknotic nuclei. Vacuolations appeared in between cells and extended to the adjacent neuropil either in the granular cell layer of the DG (fig. 2b) or pyramidal cell layer (fig. 2c).

Administration of melatonin in group 6 restored the normal laminar organization of the hippocampus (fig. 3a) and also decreased both the degenerated cells and the vacuolations either in the granular cell layer of the DG (fig. 3b) or pyramidal cell layer of CA (fig.3c).

The control, corn oil, ethanol and melatonintreated groups showed normal architecture of pituitary gland, in which pars distalis of the adenohypophysis (anterior lobe) accounts for about $75 \%$ of the hypophyseal (pituitary gland) tissue (fig.4a). The glandular cells are arranged in irregular clumps or cords between a network of sinusoidal capillaries (with large and irregular lamina). Connective tissue, which supports the glandular cells, is scant. Traditionally, glandular cells are subdivided into chromophobe cells and acidophil and basophil (chromophil) cells. This division into three cell types is based on their differential staining with H\&E. Acidophil cells are rounded cells, acidophilic cytoplasm and typically smaller than basophil cells which have basophilic cytoplasm. Acidophil cells account for roughly $65 \%$ of the cells in the adenohypophysis. Chromophobe cells are unstained or weakly stained cells (fig. 4b).

The deltamethrin- treated group showed that the pars distalis had decreased cellular density, and dilated congested capillaries (fig. $5 \mathrm{a} \&$ b). While administration of melatonin in group 6 restores the cellular density. Capillaries appeared to be normal without dilatation or congestion (fig. 6a \& b) (table 5).

There was no detectable immunoreactivity for p-53 in the hippocampus of the control, corn oil, ethanol and melatonin groups (fig. 7a). In group 5, the expression was nuclear and mainly found in the granular cell layer of DG and pyramidal cell layer in CA1, CA3 (fig. 7b). There was little immunoreactivity in few cells scattered all over the hippocampus in group 6 (fig. $7 \mathrm{c}$ ).

There was no detectable immunoreactivity for p-53 in the pars distalis of the adenohypophysis of the control, corn oil, ethanol, and melatonin groups (fig. 8 a). In group 5 , the expression for $\mathrm{p}-53$ was obvious as there was large amount of p-53 positive cells. Also, immunolabeled cells and p-53-labeled remnants of apoptotic material were apparent around and within a sinusoidal lumen; most probably macrophages phagocytozing remnants of apoptotic cells (fig. 8b). On the other hand, there was a little immunoreactivity in a few cells in group 6 (fig. 8c) (table 5).

Table (1): Student's t-test statistical analysis of MDA level in the hippocampus in different experimental groups $(\mathbf{n}=\mathbf{1 0})$.

\begin{tabular}{|l|c|c|c|c|c|c|}
\hline \multirow{2}{*}{$\begin{array}{l}\text { Group } \\
\text { Mean } \pm \text { SD }\end{array}$} & \multicolumn{7}{|c|}{ MDA level (nmol/gm tissue) } \\
\cline { 2 - 7 } & $\begin{array}{c}\text { Group (1) } \\
\mathbf{9 0} \pm \mathbf{1 . 5}\end{array}$ & $\begin{array}{c}\text { Group (2) } \\
\mathbf{9 0 . 0 1} \pm \mathbf{1 . 6}\end{array}$ & $\begin{array}{c}\text { Group (3) } \\
\mathbf{9 1 . 8} \pm \mathbf{1 . 2}\end{array}$ & $\begin{array}{c}\text { Group(4) } \\
\mathbf{9 1 . 1} \pm \mathbf{0 . 9 8}\end{array}$ & $\begin{array}{c}\text { Group (5) } \\
\mathbf{1 2 0 . 1} \pm \mathbf{3 . 1}\end{array}$ & $\begin{array}{c}\text { Group (6) } \\
\mathbf{1 0 0 . 0 2} \pm \mathbf{0 . 5 7}\end{array}$ \\
\hline Group (1) & & 0.07 & 0.3 & 0.2 & $0.00004^{*}$ & $0.00002^{*}$ \\
\hline Group (2) & 0.07 & & 0.08 & 0.4 & $0.00002^{*}$ & $0.00002^{*}$ \\
\hline Group (3) & 0.3 & 0.08 & & 0.7 & $0.00001^{*}$ & $0.00001^{*}$ \\
\hline Group(4) & 0.2 & 0.4 & 0.7 & & $0.00004^{*}$ & $0.0002^{* *}$ \\
\hline Group (5) & $0.00004^{*}$ & $0.00002^{*}$ & $0.00001^{*}$ & $0.00004^{*}$ & & $0.00002^{*}$ \\
\hline Group (6) & $0.00002^{*}$ & $0.00002^{*}$ & $0.00001^{*}$ & $0.0002^{* *}$ & $0.00002^{*}$ & \\
\hline
\end{tabular}

$* P<0.0001$ : very highly significant; $* * P<0.001$ : highly significant; $* * * p<0.05:$ significant; $P>0.05:$ non-significant SD: standard deviation

Table (2): Student's t-test statistical analysis of reduced glutathione level in the hippocampus in different experimental groups $(n=10)$.

\begin{tabular}{|l|c|c|c|c|c|c|}
\hline \multirow{2}{*}{$\begin{array}{l}\text { Group } \\
\text { Mean } \pm \text { SD }\end{array}$} & $\begin{array}{c}\text { Group (1) } \\
\mathbf{1 8 . 7} \pm \mathbf{0 . 8 9}\end{array}$ & $\begin{array}{c}\text { Group (2) } \\
\mathbf{1 8 . 7} \pm \mathbf{0 . 7 2}\end{array}$ & $\begin{array}{c}\text { Group (3) } \\
\mathbf{1 9 . 5} \pm \mathbf{1 . 2}\end{array}$ & $\begin{array}{c}\text { Group(4) } \\
\mathbf{1 9 . 1} \pm \mathbf{1 . 3}\end{array}$ & $\begin{array}{c}\text { Group (5) } \\
\mathbf{1 0 . 6 4} \pm \mathbf{2 . 2}\end{array}$ & $\begin{array}{c}\text { Group (6) } \\
\mathbf{1 5 . 4 9} \pm \mathbf{1 . 9}\end{array}$ \\
\hline Group (1) & & 0.09 & 0.2 & 0.4 & $0.00004^{*}$ & $0.0002^{* *}$ \\
\hline Group (2) & 0.09 & & 0.07 & 0.3 & $0.00002^{*}$ & $0.0002^{* *}$ \\
\hline Group (3) & 0.2 & 0.07 & & 0.7 & $0.00001^{*}$ & $0.0001^{* *}$ \\
\hline Group(4) & 0.4 & 0.3 & 0.7 & & $0.00003^{*}$ & $0.0002^{* *}$ \\
\hline Group (5) & $0.00004^{*}$ & $0.00002^{*}$ & $0.00001^{*}$ & $0.00003^{*}$ & & $0.00002^{*}$ \\
\hline Group (6) & $0.0002^{* *}$ & $0.0002^{*}$ & $0.0001^{* *}$ & $0.0002^{* *}$ & $0.00002^{*}$ & \\
\hline
\end{tabular}

$* P<0.0001$ : very highly significant; ${ }^{* *} P<0.001$ : highly significant; $* * * p<0.05:$ significant; $P>0.05:$ non-significant SD: standard deviation 
Table (3): Student's t-test statistical analysis of catalase level in the hippocampus in different experimental groups $(\mathbf{n}=10)$.

\begin{tabular}{|l|c|c|c|c|c|c|}
\hline \multirow{2}{*}{$\begin{array}{l}\text { Group } \\
\text { Mean } \pm \text { SD }\end{array}$} & $\begin{array}{c}\text { Group (1) } \\
\mathbf{2 0 . 9 8} \pm \mathbf{0 . 5 9}\end{array}$ & $\begin{array}{c}\text { Group (2) } \\
\mathbf{2 0 . 8} \pm \mathbf{0 . 5 2}\end{array}$ & $\begin{array}{c}\text { Group (3) } \\
\mathbf{2 1 . 8} \pm \mathbf{1 . 2}\end{array}$ & $\begin{array}{c}\text { Group(4) } \\
\mathbf{2 1 . 0 1} \pm \mathbf{1 . 3}\end{array}$ & $\begin{array}{c}\text { Group (5) } \\
\mathbf{1 1 . 6 4} \pm \mathbf{2 . 5}\end{array}$ & $\begin{array}{c}\text { Group (6) } \\
\mathbf{1 6 . 9 8} \pm \mathbf{2 . 9}\end{array}$ \\
\hline Group (1) & & 0.04 & 0.2 & 0.5 & $0.00003^{*}$ & $0.0002^{* *}$ \\
\hline Group (2) & 0.09 & & 0.09 & 0.6 & $0.00004^{*}$ & $0.0001^{* *}$ \\
\hline Group (3) & 0.2 & 0.09 & & 0.8 & $0.00001^{*}$ & $0.0001^{* *}$ \\
\hline Group(4) & 0.5 & 0.6 & 0.8 & & $0.00002^{*}$ & $0.0004^{* *}$ \\
\hline Group (5) & $0.00003^{*}$ & $0.00004^{*}$ & $0.00001^{*}$ & $0.00002^{*}$ & & $0.00002^{*}$ \\
\hline Group (6) & $0.0002^{* *}$ & $0.0001^{* *}$ & $0.0001^{* *}$ & $0.0004^{* *}$ & $0.00002^{*}$ & \\
\hline
\end{tabular}

$* P<0.0001$ : very highly significant; $* * P<0.001$ : highly significant; $* * * p<0.05:$ significant; $P>0.05:$ non-significant $S D$ : standard deviation

Table (4): Student's t-test statistical analysis of ACTH and cortisol levels in different experimental groups $(\mathbf{n}=\mathbf{1 0})$.

\begin{tabular}{|c|c|c|c|c|c|c|}
\hline \multirow[b]{2}{*}{$\begin{array}{l}\text { Group } \\
\text { Mean } \pm \text { SD }\end{array}$} & \multicolumn{6}{|c|}{ ACTH level (Pg/mI) } \\
\hline & $\begin{array}{c}\text { Group (1) } \\
105.62 \pm 2.1\end{array}$ & $\begin{array}{c}\text { Group (2) } \\
105.58 \pm 1.9\end{array}$ & $\begin{array}{l}\text { Group (3) } \\
106.1 \pm 2.2\end{array}$ & $\begin{array}{c}\text { Group(4) } \\
105.53 \pm 1.8\end{array}$ & $\begin{array}{l}\text { Group (5) } \\
73.5 \pm 0.59\end{array}$ & $\begin{array}{c}\text { Group (6) } \\
90.76 \pm 0.89\end{array}$ \\
\hline Group (1) & & 0.5 & 0.08 & 0.09 & $0.00001^{*}$ & $0.0001 * *$ \\
\hline Group (2) & 0.5 & & 0.09 & 0.6 & $0.00003 *$ & $0.0001 * *$ \\
\hline Group (3) & 0.08 & 0.09 & & 0.7 & $0.00001 *$ & $0.0001 * *$ \\
\hline Group(4) & 0.09 & 0.6 & 0.7 & & $0.00004 *$ & $0.0002 * *$ \\
\hline Group (5) & $0.00001 *$ & $0.00003 *$ & $0.00001 *$ & $0.00004 *$ & & $0.00002 *$ \\
\hline Group (6) & $0.0001 * *$ & $0.0001 * *$ & $0.0001 * *$ & $0.0002 * *$ & $0.00002 *$ & \\
\hline \multirow[b]{2}{*}{$\begin{array}{l}\text { Group } \\
\text { Mean } \pm \text { SD }\end{array}$} & \multicolumn{6}{|c|}{ Cortisol level (Ug/dl) } \\
\hline & $\begin{array}{c}\text { Group (1) } \\
99.5 \pm 1.3\end{array}$ & $\begin{array}{l}\text { Group (2) } \\
99.2 \pm 1.02\end{array}$ & $\begin{array}{c}\text { Group (3) } \\
99.8 \pm 1.2\end{array}$ & $\begin{array}{l}\text { Group(4) } \\
98.85 \pm 1.5\end{array}$ & $\begin{array}{c}\text { Group (5) } \\
43.42 \pm 0.54\end{array}$ & $\begin{array}{l}\text { Group (6) } \\
84.02 \pm 2.6\end{array}$ \\
\hline Group (1) & & 0.06 & 0.08 & 0.5 & $0.00004 *$ & $0.0002 * *$ \\
\hline Group (2) & 0.06 & & 0.04 & 0.6 & $0.00006^{*}$ & $0.0001 * *$ \\
\hline Group (3) & 0.08 & 0.04 & & 0.04 & $0.00003 *$ & $0.0002 * *$ \\
\hline Group(4) & 0.5 & 0.6 & 0.04 & & $0.00001 *$ & $0.0002 * *$ \\
\hline Group (5) & $0.00004 *$ & $0.00006^{*}$ & $0.00003 *$ & $0.00001 *$ & & $0.0001 * *$ \\
\hline Group (6) & $0.0002 * *$ & $0.0001 * *$ & $0.0002 * *$ & $0.0002^{* *}$ & $0.0001 * *$ & \\
\hline
\end{tabular}

$* P<0.0001$ : very highly significant; $* * P<0.001$ : highly significant; $* * * p<0.05:$ significant; $P>0.05:$ non-significant $S D$ : standard deviation

Table (5): Chi-square statistical analysis of histopathological findings in different experimental groups (n=10).

\begin{tabular}{|c|c|c|c|c|c|c|c|}
\hline $\begin{array}{ll}\text { Changes } & \text { Group } \\
\end{array}$ & Group(1) & Group(2) & Group(3) & Group(4) & Group(5) & $\begin{array}{l}\text { Group } \\
\text { (6) }\end{array}$ & Chi-square \\
\hline $\begin{array}{l}\text { Disturbed laminar organization } \\
\text { of hippocampus }\end{array}$ & $\begin{array}{c}0 \\
0 \%\end{array}$ & $\begin{array}{c}0 \\
0 \%\end{array}$ & $\begin{array}{c}0 \\
0 \%\end{array}$ & $\begin{array}{c}0 \\
0 \%\end{array}$ & $\begin{array}{c}8 \\
80 \%\end{array}$ & $\begin{array}{c}2 \\
20 \%\end{array}$ & $\begin{array}{c}\mathrm{X}^{2}=32.2 \\
\mathrm{P}=0.00001 *\end{array}$ \\
\hline $\begin{array}{l}\text { Marked degenerated cells \& } \\
\text { pyknotic nuclei in } \\
\text { hippocampus }\end{array}$ & $\begin{array}{c}0 \\
0 \%\end{array}$ & $\begin{array}{c}0 \\
0 \%\end{array}$ & $\begin{array}{c}0 \\
0 \%\end{array}$ & $\begin{array}{c}0 \\
0 \%\end{array}$ & $\begin{array}{c}7 \\
70 \%\end{array}$ & $\begin{array}{c}2 \\
20 \%\end{array}$ & $\begin{array}{c}\mathrm{X}^{2}=30.5 \\
\mathrm{P}=0.0001 * *\end{array}$ \\
\hline $\begin{array}{l}\text { Vacuolations in ground and } \\
\text { pyramidal cell layer of } \\
\text { hippocampus }\end{array}$ & $\begin{array}{c}0 \\
0 \%\end{array}$ & $\begin{array}{c}0 \\
0 \%\end{array}$ & $\begin{array}{c}0 \\
0 \%\end{array}$ & $\begin{array}{c}0 \\
0 \%\end{array}$ & $\begin{array}{c}9 \\
90 \%\end{array}$ & $\begin{array}{c}3 \\
30 \%\end{array}$ & $\begin{array}{c}\mathrm{X}^{2}=29.5 \\
\mathrm{P}=0.0001 * *\end{array}$ \\
\hline $\begin{array}{l}\text { Decreased cellular density of } \\
\text { pars distalis of pituitary gland }\end{array}$ & $\begin{array}{c}0 \\
0 \%\end{array}$ & $\begin{array}{c}0 \\
0 \%\end{array}$ & $\begin{array}{c}0 \\
0 \%\end{array}$ & $\begin{array}{c}0 \\
0 \%\end{array}$ & $\begin{array}{c}9 \\
90 \% \\
\end{array}$ & $\begin{array}{c}2 \\
20 \% \\
\end{array}$ & $\begin{array}{c}\mathrm{X}^{2}=32.5 \\
\mathrm{P}=0.00001 *\end{array}$ \\
\hline $\begin{array}{l}\text { Dilated congested capillaries } \\
\text { of pars distalis of pituitary } \\
\text { gland }\end{array}$ & $\begin{array}{c}0 \\
0 \%\end{array}$ & $\begin{array}{c}0 \\
0 \%\end{array}$ & $\begin{array}{c}0 \\
0 \%\end{array}$ & $\begin{array}{c}0 \\
0 \%\end{array}$ & $\begin{array}{c}8 \\
80 \%\end{array}$ & $\begin{array}{c}0 \\
0 \%\end{array}$ & $\begin{array}{c}\mathrm{X}^{2}=35.2 \\
\mathrm{P}=0.00001 *\end{array}$ \\
\hline $\begin{array}{l}\text { Detectable marked } \\
\text { immunoreactivity for P. } 53 \text { in } \\
\text { hippocampus \& pituitary gland }\end{array}$ & $\begin{array}{c}0 \\
0 \%\end{array}$ & $\begin{array}{c}0 \\
0 \%\end{array}$ & $\begin{array}{c}0 \\
0 \%\end{array}$ & $\begin{array}{c}0 \\
0 \%\end{array}$ & $\begin{array}{c}9 \\
90 \%\end{array}$ & $\begin{array}{c}1 \\
10 \%\end{array}$ & $\begin{array}{c}\mathrm{X}^{2}=36.2 \\
\mathrm{P}=0.00001 *\end{array}$ \\
\hline
\end{tabular}

$* P<0.0001$ : very highly significant; ${ }^{* *} P<0.001$ : highly significant; $* * * p<0.05:$ significant; $P>0.05:$ non-significant 


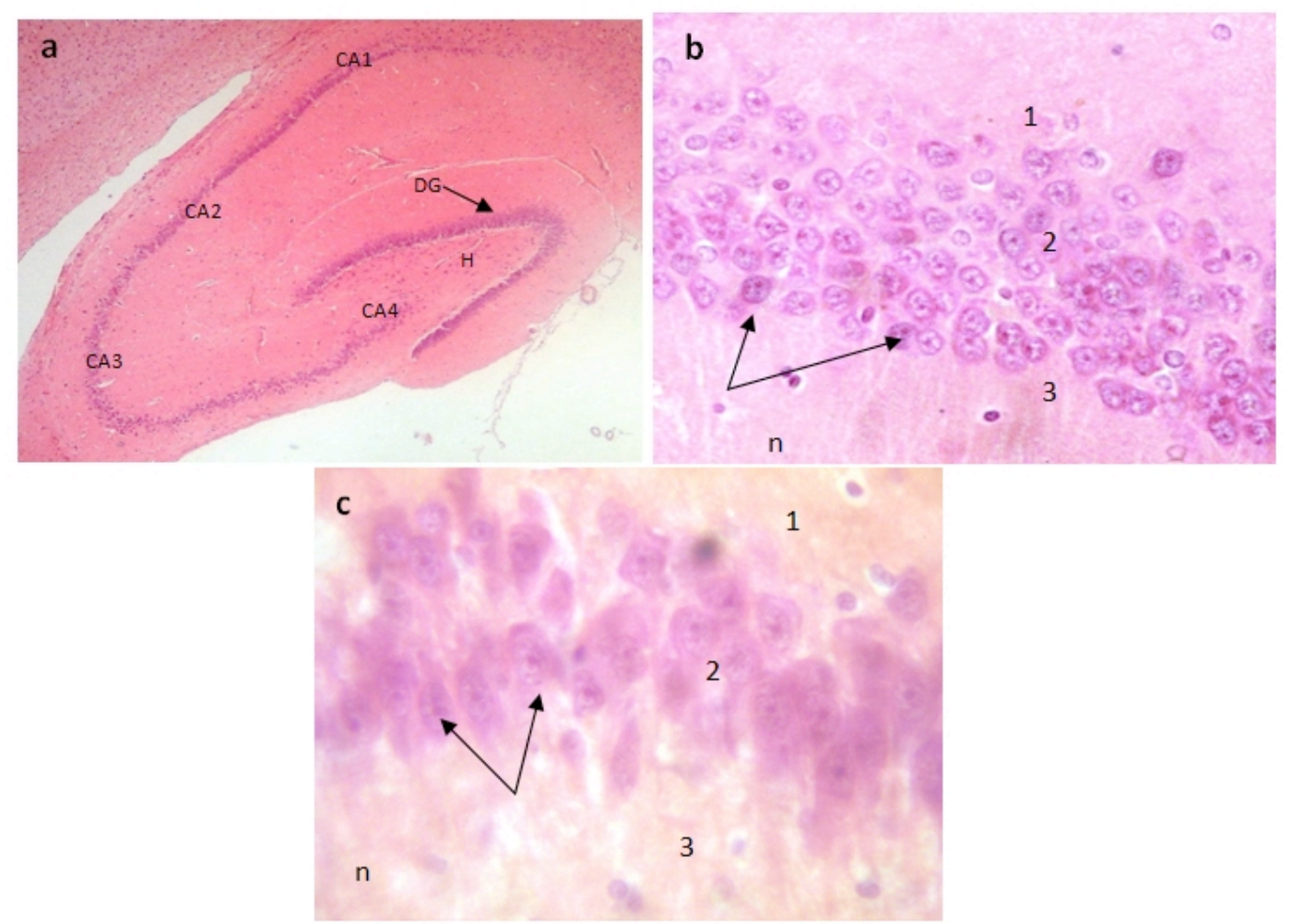

Figure 1: Photomicrographs of the hippocampus of groups $(1,2,3$ \& $n)$ showing: 1a) Cornu ammonis (CA): CA1, CA2, CA3, CA4 zones, the dentate gyrus (DG), and the hilus (H). 1b) Normal neuronal cell bodies with vesicular nuclei and prominent nucleoli (arrows) in the granular cell layer of the DG. 1c) Normal pyramidal cell bodies with vesicular nuclei and prominent nucleoli (arrows) in the pyramidal cell layer of CA. Cells are densely packed. 1: superficial molecular layer, 2: cell (granular or pyramidal) layer and 3: polymorphic layer. Notice the densely packed cells and normal neuropil (n). H\&E aX 10, b\&cX 100.

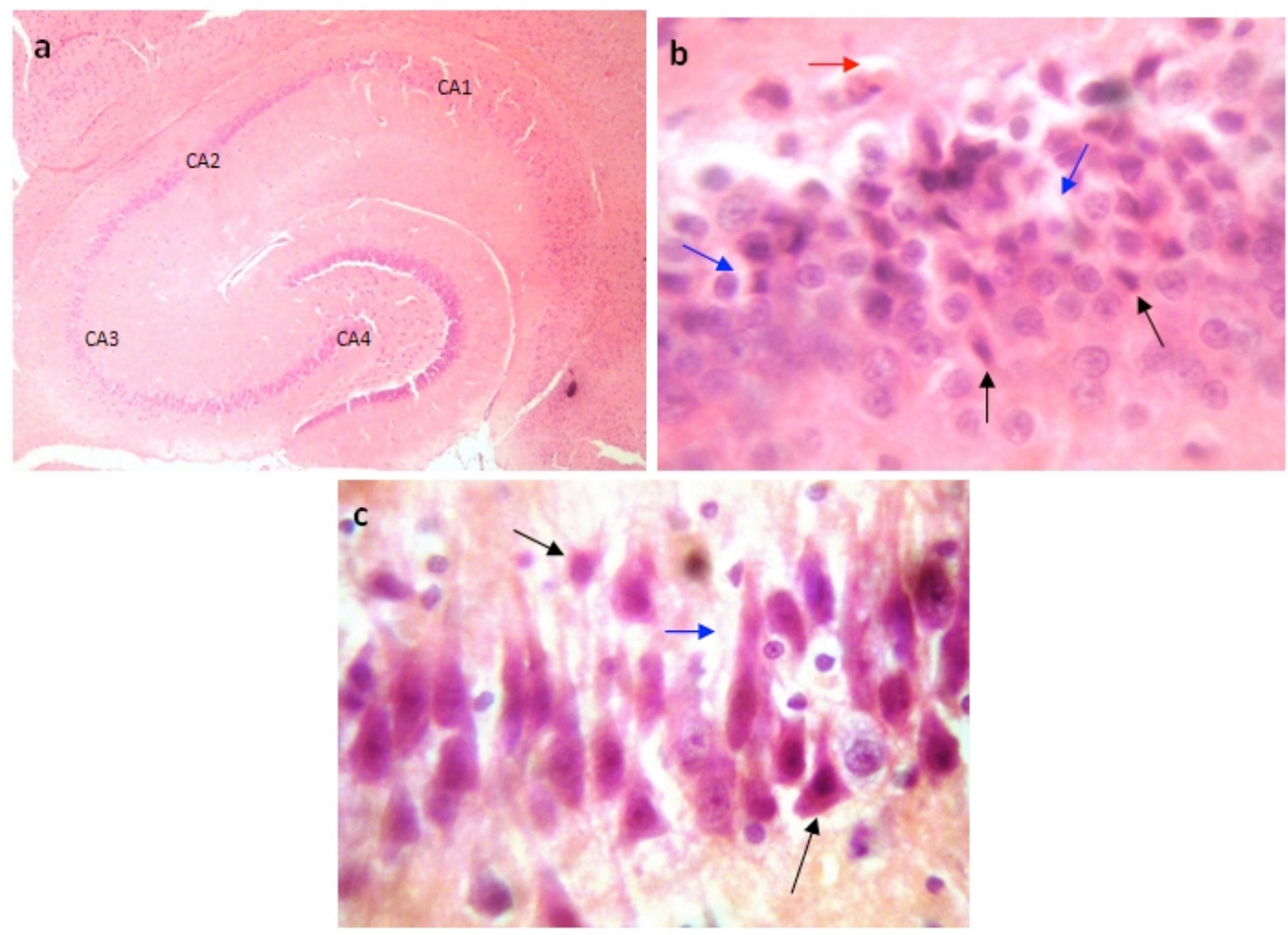

Figure 2: Photomicrographs of the hippocampus of group 5 showing: a) disruption of normal laminar organization with widely spaced cells and decreased cellular density especially in CA1 and CA3 zones (arrows). (b) Disturbed laminar organization of granular cell layer of the DG and pyramidal cell layer of CA (c) Degenerated neurons with shrunken, dense acidophilic cytoplasm \& dark condensed pyknotic nuclei (black arrows). Notice vacuolations in between cells (blue arrows) and extend to the adjacent neuropil (red arrow). H\&E a X10, b \& c X100. 

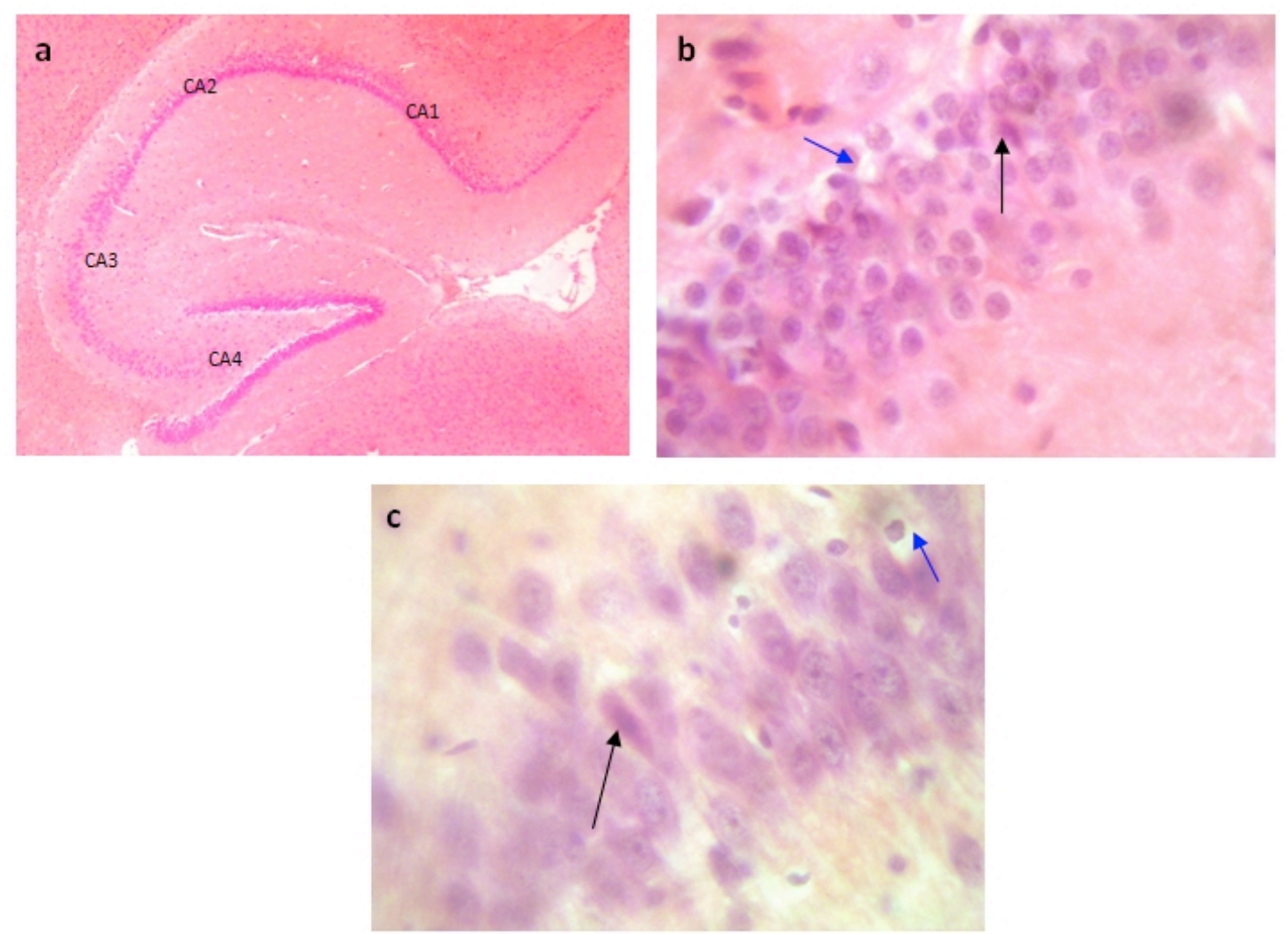

Figure 3: Photomicrographs of the hippocampus of group 6 showing: a) restored laminar organization with increased cellular density. Few degenerated cells (black arrows) and decreased vacuolations (blue arrows) either in the granular cell layer of the DG (b) or pyramidal cell layer of CA (c). H\&E a X10, b \& c X100.
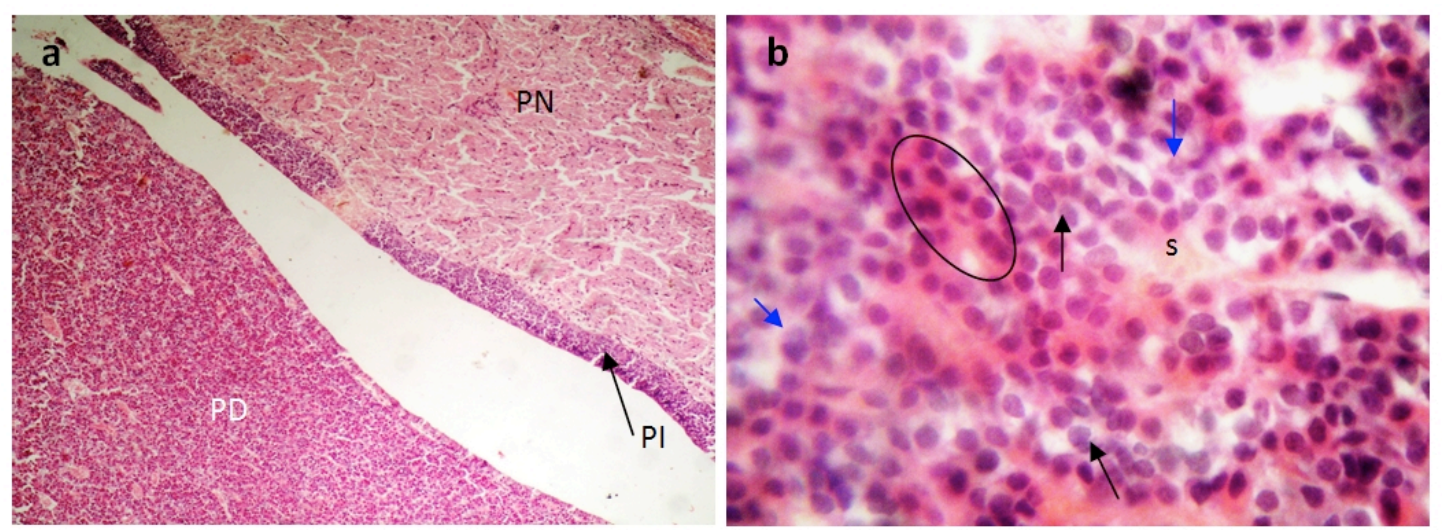

Figure 4: Photomicrographs of rat pituitary gland of groups (1, 2, 3 \&4) showing: a) Pars Distalis of the adenohypophysis (PD), Pars Intermedia (PI), and pars nervosa (PN) of the neurohypophysis. b) Different cell types of PD: acidophils (circle), basophils (blue arrow), and chromophobes (black arrow). Notice large sinusoidal capillaries (s). H\&E a X10, b X100. 

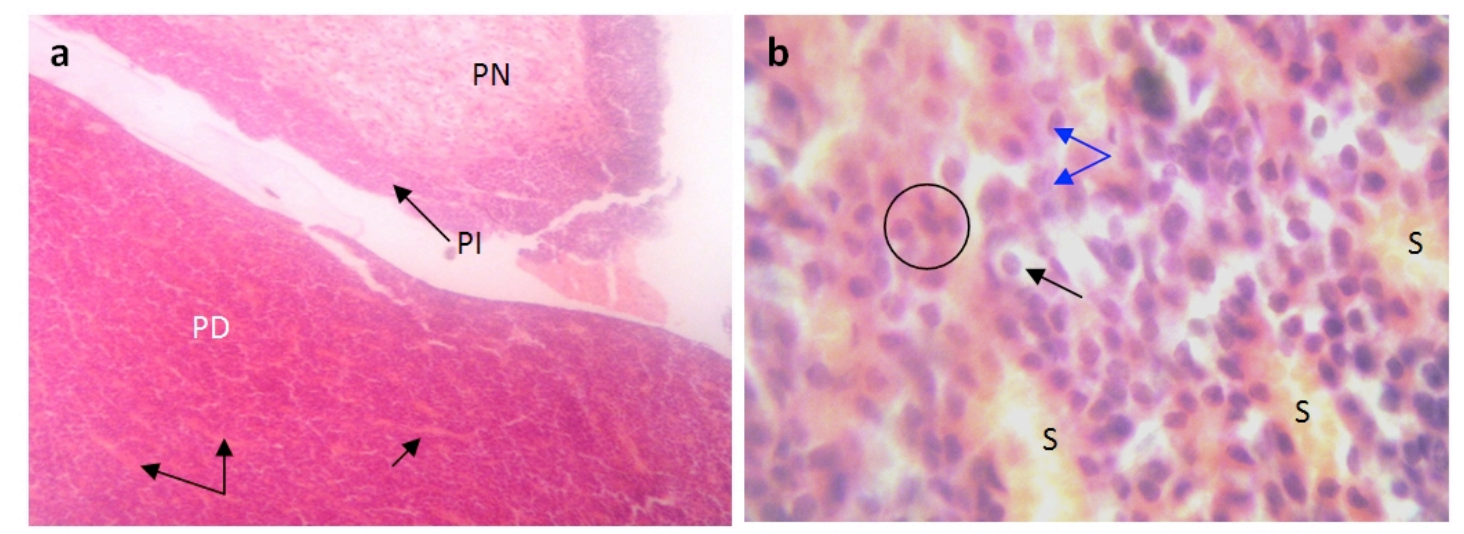

Figure 5: Photomicrographs of pituitary gland of group 5 showing: a) pars distalis of the adenohypophysis (PD) with congested and dilated sinusoids (arrows), Pars Intermedia (PI), and pars nervosa (PN) of the neurohypophysis. b) PD showing decreased cell amount and congested and dilated sinusoids(s). Acidophils (circle), basophils (blue arrow), and chromophobes (black arrow). H\&E a X10, b X100.
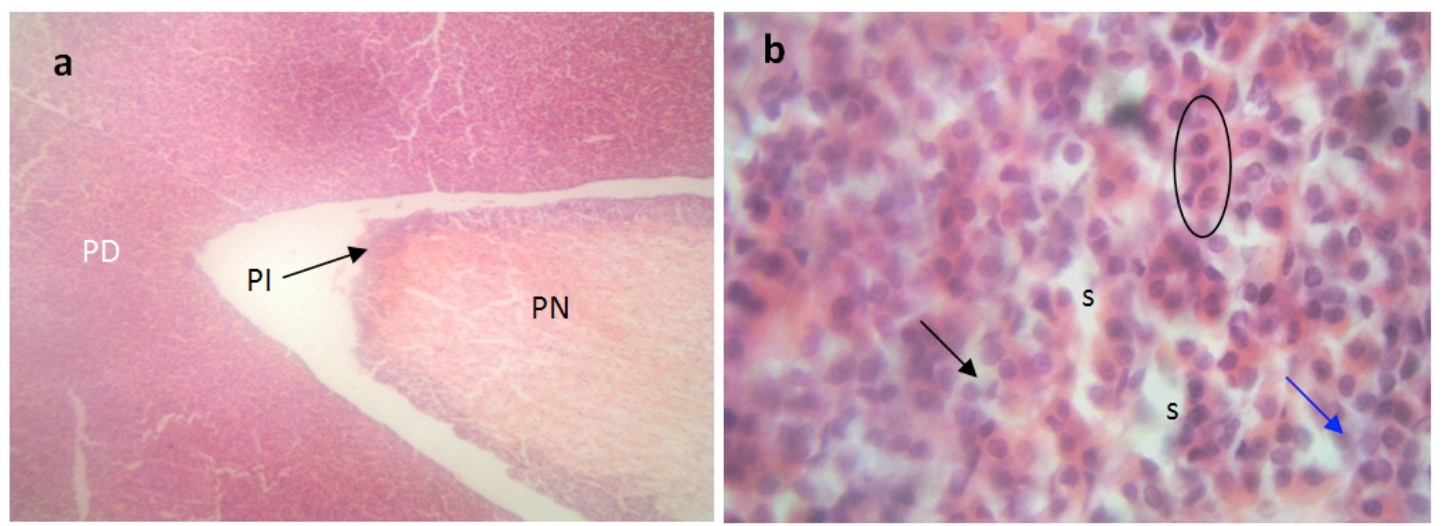

Figure 6: Photomicrographs of pituitary gland of group 6 showing: a) pars distalis of the adenohypophysis (PD), Pars Intermedia (PI), and pars nervosa (PN) of the neurohypophysis. b) PD with aberrant normal cell amount and sinusoids with no congestion(s). Acidophils (circle), basophils (blue arrow), and chromophobes (black arrow). H\&E a X10, b X100. 

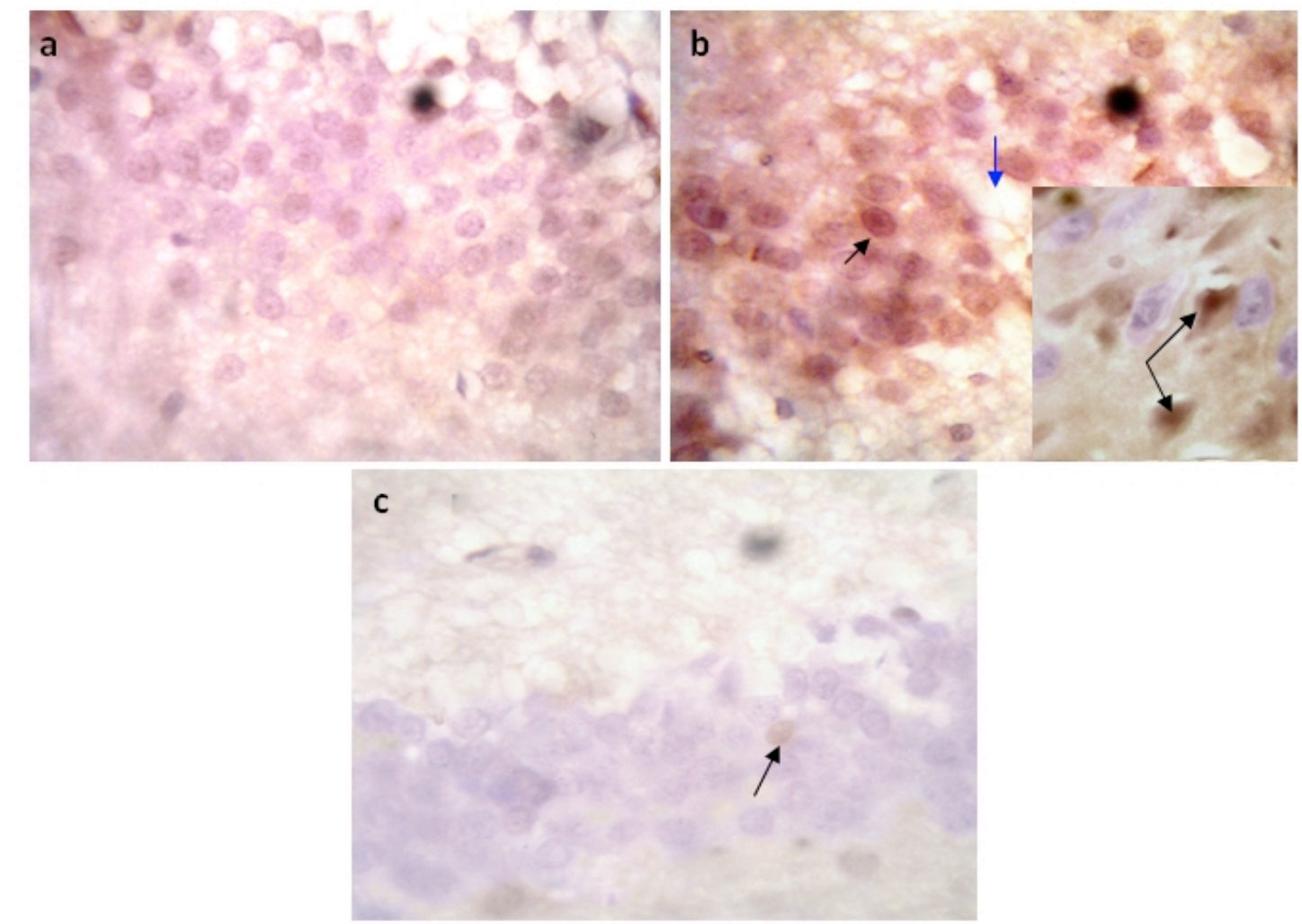

Figure 7: Rat hippocampus tissues labeled for p-53 in: a) groups 1,2,3,4 showed no detectable immunolabeling. b) Group 5 showed immunolabeled cells (arrows). Notice vacuolations between cells (blue arrow). c) Group 6 showed very few immunolabeled cells (arrow). Immunohistochemistry, counterstained with H X100.
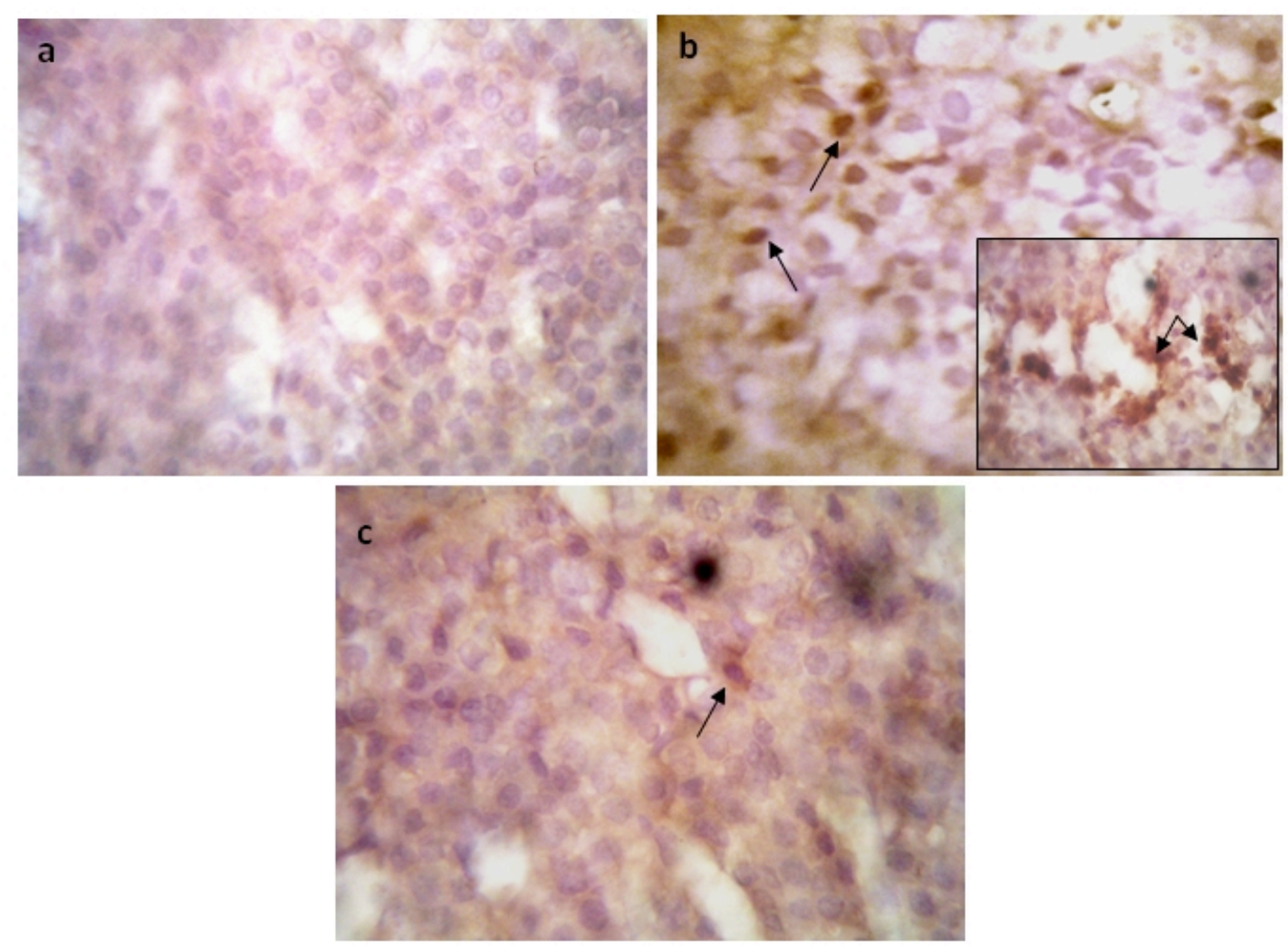

Figure 8: Rat pituitary glands labeled for p-53 in: a) groups 1,2,3,4 showed no detectable immunolabeling. b) Group 5 showed immunolabeled cells (arrows). Notice decreased cellular density. The inset showed immunolabeled cells and p-53-labeled remnants of apoptotic material around and within a sinusoidal lumen (arrows); most probably macrophages phagocytozing remnants of apoptotic cells. c) Group 6 showing very few immunolabeled cells (arrow). Immunohistochemistry, counterstained with H X100. 


\section{Discussion}

Synthetic pyrethroids are considered a group of insecticides having pyrethrum like structures with better performance characteristics and account for over $30 \%$ of insecticides used globally (Prasanthi et al., 2005).

Deltamethrin is one of the most neuro-toxic members of a relatively new and commonly used class of the pyrethroid insecticides It is the most toxic pyrethroid used for vertebrates and it is used extensively not only as an ectoparasiticide in animals but also, in agricultural crop production and in public health programs. The main sources of general population exposure to this pesticide are contaminated food and water (Kim et al., 2008).

Apoptosis is a form of active cell death, distinct from necrosis, playing an important role not only in physiological but also in pathological conditions. The synthetic pyrethroid deltamethrin was also found to induce neurodegeneration and apoptotic cell death in rat brain (Ercüment et al., 2010).

The objective of this study was to assess the toxicity of deltamethrin on hippocampus and pituitary gland, through measuring serum ACTH level and plasma cortisol level and oxidative stress marker (MDA, GSH and catalase) in hippocampus and the role of melatonin as a protective agent.

In the present study, deltamethrin was given at a dose of $12.5 \mathrm{mg} / \mathrm{Kg}$ bw daily IP $\left(15 \%\right.$ of $\mathrm{LD}_{50}$ of deltamethrin) according to Aiguo and Yugu, (2000). Severe pathological changes were observed in the hippocampus and pituitary gland of rats, although none of the rats died during the experimental period. While, in the study of Sabina et al., 2001, deltamethrin was given at $1 / 10$ of the $\mathrm{LD}_{50}$ and produced severe degenerative changes in the liver and kidneys in mice.

The present study proved that chronic deltamethrin exposure induced pathological changes in the hippocampus and pituitary gland in the form of the presence of a large amount of degenerated cells with densely stained, shrunk acidophilic cytoplasm and dark condensed pyknotic nuclei and vacuolations appeared in between the cells of hippocampus. The pars distalis of the pituitary gland had decreased cellular density, and dilated congested capillaries. These results are in agreement with the study of Aiguo and Yugu, (2000).

This present study showed also increased amount of immunolabeled P-53 positive cells in the granular cell layer of dentate gyrus in the hippocampus and around and within the sinusoidal lumen of the pars distalis of adenohypophysis of pituitary gland. These results are in agreement with the study of Aiguo et al., (2000).

The pathological changes and oxidative damage induced by deltamethrin and other pyrethroids can be explained by their lipophilicity, whereby they could penetrate the cell membrane easily, pyrethroids indirectly generate various radicals as superoxide radical, nitrogen species such as feroxynitrite, nitric oxide and hydroxyl radical thus causing damage consistent with oxidative stress (Celik and Suzek, 2009).

Elhalwagy et al., (2008) reported that the released oxygen free radicals attack the cell membrane and lead to destabilization and disintegration of cell membrane as a result of lipid peroxidation. Also, pyrethroids cause increase of lipid peroxidation through its interference with membrane dependent processes.

Wang et al., (2005) reported that melatonin rapidly crosses the blood- brain barrier after systemic administration and is distributed to the cerebrospinal fluid and throughout the different regions of the brain. In the present study, pretreatment of melatonin with deltamethrin restored the normal laminar organization of the hippocampus and decreased both the degenerated cells and vacuolations in the hippocampus \& pituitary gland. Also, melatonin produced little immunoreactivity for P-53 in a few cells scattered all over the hippocampus and pituitary gland. These results are in agreement with the results of Hala et al., (2009) .Their study revealed that melatonin has an ameliorating effect against deltamethrin- induced oxidative damage in hippocampus, cerebral cortex, and cerebellum of rats.

Chronic administration of deltamethrin in this study led to significant brain (hippocampus) toxicity which is represented by increased level of lipid peroxides (MDA), in addition, there was a significant decrease in antioxidant enzymes as GSH and catalase contents of hippocampus homogenate. These results agree with the results of Somia et al., (2010). Their study revealed that repeated dose toxicity of deltamethrin altered the biochemical parameters, decreased cytochrome P450 content and antioxidant status (GSH, catalase, superoxide dismutase) in many organs such as lungs, liver, kidneys, hippocampus and cerebellum which correlated with histopathological changes induced by deltamethrin in these organs.

Eradal et al., (2002) conducted a study to explain the oxidative stress induced by organophosphorous compounds and pyrethroids. Oxidative stress occurs when the production of ROS overrides the antioxidant capability in the target cell, resulting in oxidative damage due to the interaction of ROS with critical cellular macromolecules. ROS may interact with cellular protein, lipid, and DNA, causing alterations in the target cell function.

Pretreatment of melatonin with deltamethrin in this present study induced a significant lower MDA level and a significant higher GSH \& catalase levels. These results are in agreement with the results of the study of Sun et al., (2007) who conducted a study that 
revealed that melatonin has a protective effect on deltamethrin -induced oxidative damage in hippocampus.

The cell has several ways to alleviate the effects of oxidative stress either by repairing the damage (damaged nucleotides and lipid peroxidation by- products) or by directly reducing the pro-oxidative state via enzymatic and non- enzymatic antioxidants. Non- enzymatic (vitamin E \& C, melatonin, urate, etc) and enzymatic (catalase, superoxide dismutase, etc) antioxidants have been shown to scavenge free radicals and ROS (Gultekin et al., 2001).

The hypothalamic- pituitary- adrenal (HPA) axis is a complex set of direct influences and feedback interactions among the hypothalamus, the pituitary gland, and the suprarenal gland. The interactions among these organs constitute a major part of the neuroendocrine system that controls reactions to stress and regulate many body processes. Exposure to any type of stress e.g social stress, physical or even oxidative stress affect the HPA axis leading to decrease of the hormones secreted through this axis (Douglas, 2005).

Oxidative stress induced by deltamethrin in this study led to decrease in the level of serum ACTH and plasma cortisol level. Pretreatment of melatonin with deltamethrin in this study led to significant increase in the level of the previous hormones. These results are in agreement with the results of John et al., (2009) .Their study revealed that repeated exposure to deltamethrin and other pyrethroids produce vigorous autonomic and neuro endocrine responses that indicate high levels of oxidative stress induced by these insecticides which can be decreased by concomitant treatment of melatonin.

In conclusion, the present study showed that repeated exposure to deltamethrin causes neurotoxicity and melatonin has an ameliorating role on this toxicity concerning histopathological changes, oxidative stress and hormonal changes. Thus, it is advised that the Ministry of Agriculture has to cooperate with the Ministry of Health to administer melatonin preparations to farmers dealing with pyrethroid insecticides especially deltamethrin to protect them against their toxicity.

\section{References}

Aebi H (1984): Methods Enzymol. 105: pp. 121-126.

Aiguo W and Yugu L (2000): Apoptotic cell death in rat brain following deltamethrin treatment. Neuroscience Letteres. 279: pp. 85-88.

Aiguo W, Tieling R, Qiansheng $\mathrm{H}$ et al., (2000): Deltamethrin induces altered expression of P53, Bax and Bcl-2 in rat brain. Neuroscience Letteres. 284: pp. 29-32.

Bagchi D, Bagch M, Hassoun E et al., (1995): In vitro and in vivo generation of reactive oxygen species, DNA damage and lactate dehydrogenase leakage by selected pesticides. Toxicology. 104: pp.129-140.

Bagchi D, Bhattacharya G, and Stohs SJ (1996): In vitro and in vivo induction of heat shock (stress) protein (Hsp) gene expression by selected pesticides. Toxicology. 112: pp.5766.

Bancroft JD, Stevens A, and Turner DR (2002): Theory and practice of histological techniques. $4^{\text {th }}$ ed., New York: Churchill Livingstone, Ch. 3. pp. 564-388.

Beutler E, Duron O, and Kelly MB (1963): .J. Lab. Clin. Med. 61: pp. 882.

Celik I and Suzek H (2009): Effects of subacute exposure of dichlorovos at sublethal dosages on erythrocyte and tissue antioxidant defense systems and lipid peroxidation in rats. Ecotoxicol. Environ. Saf. 72: pp. 905- 908.

Ceyhun SB, Senturk M, Ekinci D et al., (2010): Deltamethrin attenuates antioxidant defense system and induces expression of heat shock protein 70 in rainbow trout. Comp Biochem Physiol. 152:pp. 215-223.

Cote A, Silva R, and Cuello AC (1993): Current protocols for light microscopy immunohistochemistry. In: Cuello AC (ed.), John Wiley \& Sons, Chichester. pp. 147- 168.

Crespi F, Ratti E, and Trist DG (1994): Melatonin, a hormone monitorable in vivo by voltammetry? Analyst D. 119: pp. 21932197.

Douglas A (2005): Central noradrenergic mechanisms underlying acute responses of the hypothalamo- pituitary- adrenal axis: adaptations through pregnancy and delivery. Stress.8: pp. 5-18.

Ekinci D and Beydemir S (2010): Risk assessment of pesticides and fungicides for acid-base regulation and salt transport in rainbow trout tissues. Pesticide Biochem Physiol. 97:pp. 6670.

Elhalwagy MEA, Darwish EM, and Zaher NS (2008): Prophylactic effects of green tea polyphenols against liver and kidney induced by feitrothion insecticide. Pest. Biochem. Physiol. 91: pp. 81-89.

Eradal K, Fatih G, Mehmet A et al., (2002): Protective role of melatonin and a combination of vitamin $\mathrm{C}$ and vitamin $\mathrm{E}$ on lung toxicity induced by chlorpyrifos- ethyl in rats. Exp. Toxic. Pathol. 54: pp. 97-108.

Ercüment A, Saltuk B, Orhan E et al., (2010): Acute and long-term genotoxicity of deltamethrin to insulin-like growth factors and growth hormone in rainbow trout. Comparative 
Biochemistry and Physiology .152: pp. 451455.

Fatma M (2011): Lipid peroxidation, oxidative stress and acetylcholinesterase in rat brain exposed to organophosphate and pyrethroid insecticides. Food and Chemical Toxicology. 49: pp. 1346-1352.

Gultekin F, Delibas N, and Yasar S (2001) : In vivo changes in antioxidant systems and protective role of melatonin and a combination of vitamin $\mathrm{C}$ and vitamin $\mathrm{E}$ on oxidative damage in erythrocytes induced by chlorpyrifos ethyl in rats. Arch Toxicol. 75: pp. 88-96.

Hala A, Nouf MI, Faddah LM et al., (2009): Ameliorating effect of idebenone and/ or melatonin against oxidative stress and energy depletion in brain of hypoxic rats. Research Journal of Medicine and Medical Sciences. 4: pp. 263- 277.

Herrero MJ, Martinez FJ, Miguez JM et al., (2006): Response of plasma and gastrointestinal melatonin, plasma cortisol and activity rhythms of European sea bass (dicentrarchess Labrax) to dietary supplementation $\mathrm{s}$ with tryptophan and melatonin. J Comp Physiol B .Doi 10.1007/ s00360-006: 0131-0136.

John D, Dana B, and Russ H (2009): Pyrethroid insecticide metabolites are associated with serum hormone levels in adult men. Reproductive Toxicology. 27:pp. 155-160.

Karbownik M and Reiter R (2000): Antioxidative effects of melatonin in protection against cellular damage caused by ionizing radiation. Proc Soc Exp Biol Med. 225: pp. 9-22.

Kim KB, Anand SS, Kim HJ et al., (2008): Toxicokinetics and tissue distribution of deltamethrin in adult Sprague- Dawley rats. Toxicol Sci. 101: pp. 197-205.

Ko"pru"cu" K and Aydin R (2004): The toxic effects of pyrethroid deltamethrin on the common carp (Cyprinus carpio L.) embryos and larvae. Pest Biochem Physiol. 80: pp. 47-53.

Krieger DT, Liolta AS, Suda T et al., (1979): Human plasma immunoreactive lipotropin and adrenocorticotropin in normal subjects and in patients with pituitary- adrenal disease. J Clin Endocrinol Metab. 48: pp. 566-571.

Lee R.F and Steinert S (2003): Use of the single cell gel electrophoresis/comet assay for detecting DNA damage in aquatic (marine and freshwater) animals. Mutat Res. pp. 544: 4364.
Mabuchi T, Kitagawa K, and Kuwabara K (2001): Phosphorylation of cAMP response elementbinding protein in hippocampal neurons as a protective response after exposure to glutamate in vitro and ischemia in vivo. The Journal of Neuroscience. 21: pp. 9204-9213.

Moore A and Waring CP (2001): The effects of a synthetic pyrethroid pesticide on some aspects of reproduction in Atlantic salmon (Salmo salar L.). Aquat Toxicol. 52: pp. 1-12.

Ohkawa H, Ohishi W, and Yagi K (1979): Biochem. 95: pp. 351.

Prasanthi K and Muralidhara PS (2005): Fenvalerateinduced oxidative damage in rat tissues and its attenuation by dietary sesame oil. Food Chem Toxicol. 43: pp. 299-306

Pratap B and Vandana S (2008): Cypermethrin induced histological changes in gonadotrophic cells, liver, gonads, plasma levels of estradiol-17b and 11-ketotestosterone, and sperm motility in Heteropneustes fossilis (Bloch). Chemosphere. 72: pp. 422-431.

Sabina T, Agnieszka H, Jadwiga L et al., (2001): Daniela O, Malgorzata T. Oral toxicity of deltamethrin and Fenvalerate in swiss mice. Ann Agric Environ Med. 8: pp. 245-254.

Sheets LP, Doherty JD, Law MW et al., (1994): Agedependent differences in the susceptibility of rats to deltamethrin. Toxicol Appl Pharmacol. 126: pp. 186-190.

Somia I, Hamady A, and Nabila S (2010): Effect of anthum Graveoles L. extract on biochemical and histopathological alteration of deltamethrin in rats. Journal of Bioanalysis \& Biomedicine. 2: pp. 008-012.

Sun H, Yu XL, Yu LC et al., (2008): Antiandrogenic activity of pyrethroid pesticides and their metabolites in reporter gene assay. Chemosphere. 66: pp. 474-9.

Tan D, Manchester L, Hardeland R et al., (2003): Melatonin: a hormone, a tissue factor, an autocoid, a paracoid, and an antioxidant vitamin. J. Pineal Res. 34:pp. 75-78.

Wang LM, Suthana NA, Claudhurg D et al., (2005): Melatonin inhibits hippocampal long- term potentation. Eur J Neuroscience. 22: pp. 22317. 
الملخص العربي

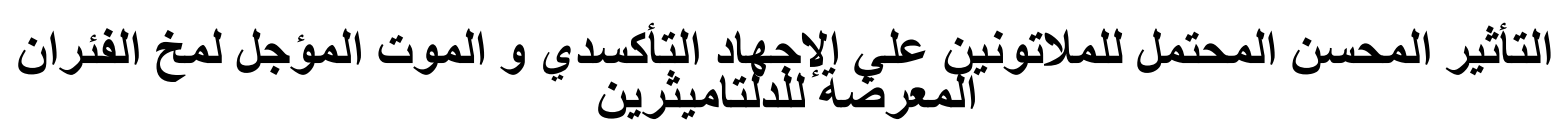

شيرين عبد الحكيم الثربينى و هالة محمد أحمد1 و نشوى فتحي الطهاوي² و أحلام محمد عبد الله

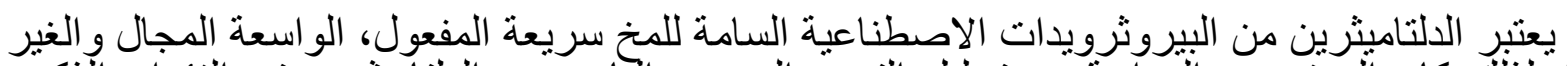

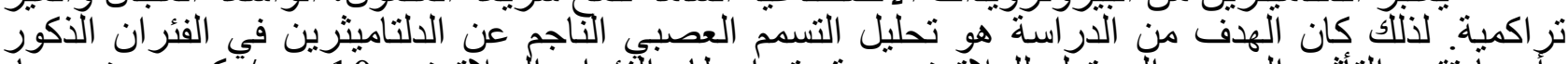

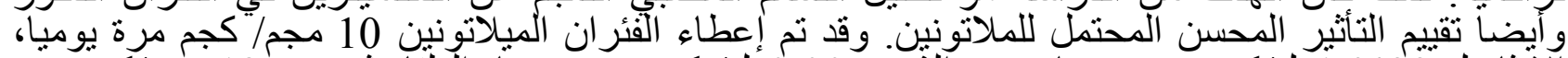

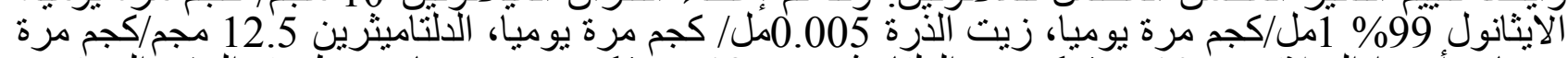

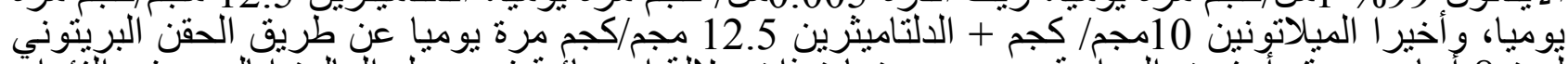

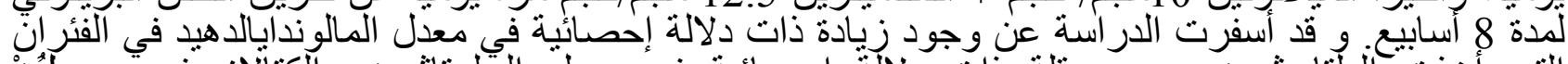

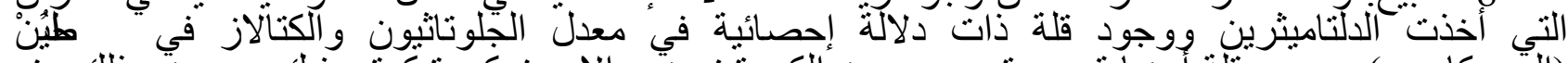

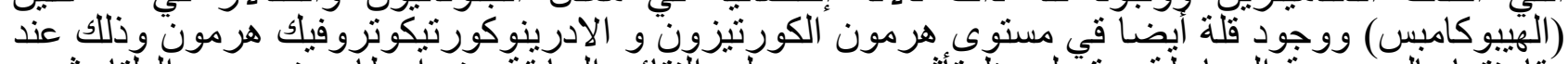

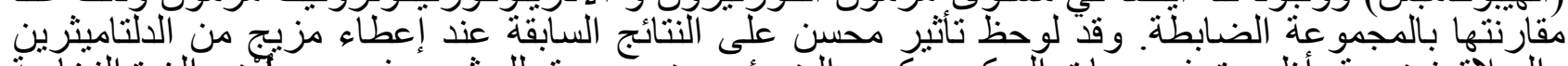

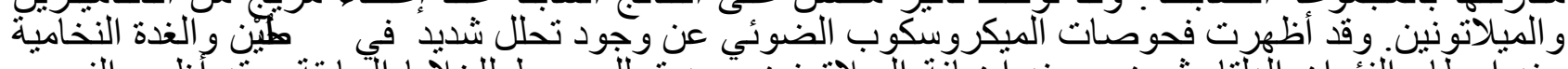

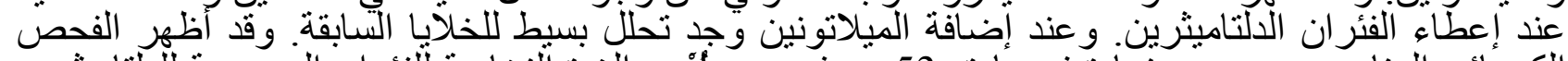

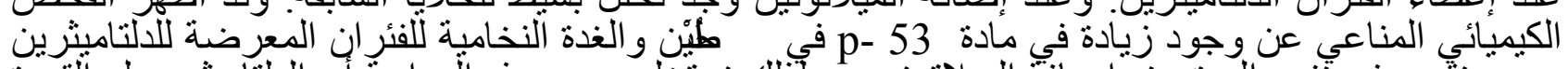

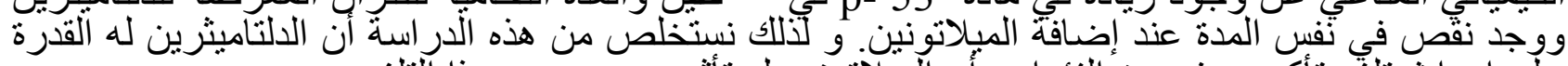

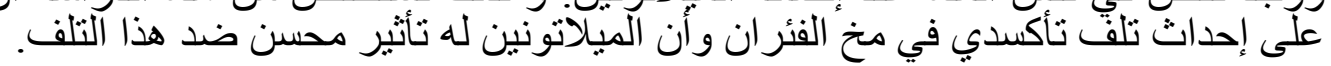

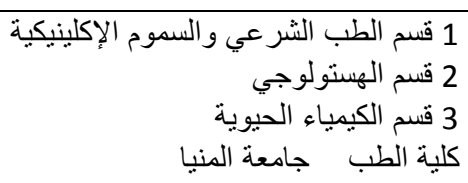


